\title{
NOS LIMIARES DA LÍNGUA: repensar a "multiplicidade" com Ondjaki e Mia Couto
}

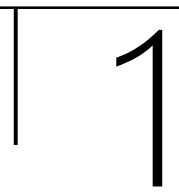

\section{ON THE THRESHOLDS OF LANGUAGE: rethinking "multiplicity" with Ondjaki and Mia Couto}

\author{
MELÃO, Dulce. \\ Doutora em Educação pela Universidade de Aveiro. Mestre em Literatura Portuguesa pela \\ Universidade de Coimbra e em Literatura Inglesa pela Lancaster, UK. \\ Professora Adjunta na Escola Superior de Educação de Viseu, Instituto Politécnico de Viseu - Portugal. \\ Membro integrado do Centro de Estudos em Educação e Inovação (CI\&DEI) \\ E-mail: dulcemelao@esev.ipv.pt \\ ORCID ID: https://orcid.org/0000-0002-1608-1074
}

\section{RESUMO}

Numa época redefinida prolificamente pela pluralidade conceptual, indagar os limiares da língua no livro-álbum contemporâneo implica-nos num exercício de reinícios que as narrativas lusófonas podem reconfigurar. Este texto procura demandar tais reinícios, de modo prolífico, centrando-se em dois livros-álbum: $O$ convidador de pirilampos (ONDJAKI, 2017) e $A$ água e a águia (COUTO, 2018). 0 enquadramento teórico deste artigo contempla: i) o conjunto de valores da literatura propostos por Italo Calvino (CALVINO, 2006); ii) a relação entre o texto e a ilustração no livro-álbum e os modos como nela se entretecem múltiplos desafios ambientais. $O$ artigo é norteado pelos seguintes objetivos: i) lançar luz sobre o caráter plural do redesenho da "multiplicidade" abrigada nas ilustrações das obras supracitadas, estimulando a participação dos leitores; ii) indagar percursos de valorização da sustentabilidade ambiental, no quadro dos objetivos globais para o desenvolvimento sustentável (PEDROSO, 2018; UNITED NATIONS, 2015), enquanto eixo conglomerador de partilhas de vozes alicerçadas no respeito pelos Outros. Conclui-se que as duas narrativas selecionadas reconstroem caminhos que reencontram nos limiares da língua amplos espaços que repetidamente apelam ao respeito pela sustentabilidade ambiental, profundamente impresso nas "estórias" narradas.

Palavras-chave: Cultura; desenvolvimento sustentável; livro-álbum; ilustração.

\section{ABSTRACT}

In an epoch prolifically redefined by conceptual plurality, questioning the thresholds of language in contemporary picturebooks implies us in an exercise of rebeginning that the lusophone narratives can reconfigure. This paper seeks to search for such new beginnings, in a prolific way, by focusing on two picturebooks: The firefly welcomer (ONDJAKI, 2017) and The water and the eagle (COUTO, 2018). The 
theoretical framework of this paper draws from: i) the set of values of literature proposed by Italo Calvino (CALVINO, 2006); ii) the relationship between the text and the illustration in the picturebook and the ways in which it intertwines multiple environmental challenges. The following objectives are outlined in this paper: i) to understand how "multiplicity" takes shelter in the illustrations of both works, stimulating the participation of readers; ii) to investigate ways of valuing environmental sustainability, in the framework of the global goals for sustainable development (PEDROSO, 2018; UNITED NATIONS, 2015), as a conglomerator axis of shared voices based on respect for Others. It is concluded that the two narratives selected reconfigure paths that meet again and again on the thresholds of language, repeatedly calling for respect for environmental sustainability, deeply imprinted in the "stories" told.

Keywords: Culture; sustainable development; picturebook; illustration.

\section{INTRODUÇÃO}

Em Seis propostas para o próximo milénio (CALVINO, 2006), Italo Calvino oferece aos leitores percursos de reflexão sobre "(...) alguns valores ou qualidades ou especificidades da literatura" (CALVINO, 2006, s/p). Profundamente ancorado na sua forma de estar no mundo, cada percurso (delineado com a gentileza e a agudez que podem unir-se no extraordinário amor pela literatura) dita ritmos distintos de releitura, colocando aos leitores o desafio de reencontrarem na língua espaços plenos de limiares que os incitam à inquietação (talvez pelos modos como aí se pode deter o seu olhar curioso e cúmplice).

Sendo certo que os exemplos que Italo Calvino aduz se traduzem na especificidade própria dos objetivos que a geraram, entendemos que os livros-álbum $O$ convidador de pirilampos (ONDJAKI, 2018) e $A$ água e a águia (COUTO, 2017), pelos movimentos da língua que convocam, no seu seio e nas suas bermas, em estreita e fundamental união com as ilustrações que os atravessam, abrem uma panóplia de conexões de grande riqueza e diversidade que podem ser lidos a partir dos fios condutores da conferência de Italo Calvino. No enquadramento teórico que apresentamos, procuramos deslindar alguns desses fios, bem como sustentar a sua relevância para os itinerários de releituras propostos.

Adicionalmente, consideramos que os peritextos ${ }^{1}$ que compõem, ecoam e eclodem nos limiares das páginas dos livros-álbum supracitados vão construindo uma ampla e segura rede de sentidos que merece atenção pelos múltiplos caminhos que possibilita percorrer. Como sublinha Calvino, na conferência que dedica à "multiplicidade" (2006, p. 134), "(...) o grande

${ }^{1}$ Adotamos, aqui, a nomenclatura usada por Gérard Genette (GENETTE, 1987). 
desafio para a literatura é o de saber tecer conjuntamente os diferentes saberes e os diferentes códigos numa visão plural e multifacetada do mundo," não se podendo pensar "(...) numa totalidade que não seja potencial, conjetural e multíplice." Das cumplicidades que se vão gerando com os leitores, potenciadas por tal visão plural e multifacetada que Calvino aponta (e que o título deste artigo acolhe), renascem, cremos, formas muito ricas de indagação que procuraremos deixar plasmadas ao longo desta reflexão.

\section{ENQUADRAMENTO TEÓRICO}

É comummente aceite a versatilidade linguística que Mia Couto e Ondjaki têm vindo a incutir nas suas narrativas (por exemplo, CAVACAS, 2015; MICHELETTI, 2017; ROTHWELL, 2015), ${ }^{2}$ sendo sublinhado o caráter inovador com que vão acolhendo o que, nesta reflexão, entendemos enquanto modos de estar na língua. Menor atenção tem sido concedida aos movimentos peritextuais que os livros-álbum que deram a lume conglomeram, enquanto sustentadores de percursos que convocam reiteradamente a participação dos leitores, contribuindo para a construção de uma matriz identitária, lugar de abrigo da língua. Entendemos que tais caminhos merecem olhares atentos porquanto possibilitam, ao mesmo tempo, reconfigurar visões do mundo que apelam à importância dos valores da literatura (Calvino, 2006), reposicionando-a enquanto modo de indagar a(s) cultura(s) para o século XXI.

Numa altura em que se reveem e se reconhecem metamorfoses perenes de práticas comunicativas favorecidas pela "democratização dos media digitais ligados em rede e das tecnologias criativas" (SOUSA, ZAGALO \& MARTINS, 2012, p. 167), consideramos, também, que importa trazer para o seio do debate lugares de ramificação da língua que nos podem ensinar que se "O mundo, mesmo partilhado, é muito a pele de cada um" (ONDJAKI, 2009, p. 25), as suas porosidades continuam a ditar trilhos de indagação pois, como frisa Mia Couto, "A cultura diz-se sempre no plural" (COUTO, 2013, p. 174). Ou, como referido de um modo inusitadamente belo, por Daniel Faria: "A diferença é o que une. / Ela é como qualquer abertura. Marcando a diferença entre dois espaços, é o que permite a ligação entre eles" (FARIA, 2019, p. 64).

\section{Em nosso entender, a pluralidade que se veste das singularidades}

\footnotetext{
2 Embora porventura menos citado, importa igualmente fazer referência, neste contexto, a José Eduardo Agualusa que, em Estranhões \& Bizarrocos. Estórias para adormecer anjos (AGUALUSA, 2000), brinda os leitores com "(...) um discurso estético criativo e inovador, favorecendo o exercício da língua, a par da promoção de competências literácitas" (SILVA, 2011, pp.128-129). Semelhante versatilidade fica, aliás, também impressa no seu invulgar Milagrário Pessoal (AGUALUSA, 2010).
} 
apontadas acima, encontra caminhos diversificados nas conferências de Italo Calvino. Não procurando realizar, neste lugar, uma análise minuciosa de tais conferências, que o escopo deste artigo não contempla, pretendemos encará-las enquanto matéria-prima que possibilite conceder espaço às indagações conglomeradas no nosso texto. Nesse sentido, apontamos alguns aspetos relacionados com as temáticas abordadas nas conferências, entrelaçando-os, de modo a construir uma constelação de sentidos a que regressamos nos itinerários posteriores que traçamos.

Italo Calvino procura situar na perspetiva do novo milénio os seguintes valores/qualidades/especificidades da literatura: i) leveza; ii) rapidez; iii) exactidão; iv) visibilidade; v) multiplicidade; vi) começar e acabar ("consistency"). ${ }^{3}$ No que se refere à "leveza," é oferecida aos leitores a projeção deste valor no futuro e a validade das razões que o sustentam. Bebendo em exemplos de Lucrécio e de Ovídeo, ${ }^{4}$ Calvino destaca que "(...) a leveza é algo que se cria na escrita, com os meios que são os do poeta" (CALVINO, 2006, p. 24). Em Boccacio encontra ensejo para dar a conhecer a relevância da imagem visual evocada nos exemplos colhidos, indeléveis na sua memória. Na Divina comédia, de Dante, detém-se na capacidade extraordinária do seu autor "(...) em extrair da língua todas as possibilidades sonoras e emocionais e de evocação de sensações" (CALVINO, 2006, p. 30). Não exclui, porém, a linguagem dotada de peso, condição que reputa de essencial para que possamos admirar o valor que defende.

$\mathrm{Se}$ as palavras podem evocar e despertar, isoladamente ou ao mesmo tempo, uma leveza erguida em filigrana ou um peso cuja opacidade também possibilita revelar múltiplos sentidos, semelhante raciocínio é desenvolvido por Calvino no que respeita à rapidez, sendo progressivamente frisados os "prazeres da lentidão" (CALVINO, 2006, p. 62). Refletindo sobre um tempo em que "(...) triunfam outros media rapidíssimos e de raio de ação extremamente amplo, arriscando-se a reduzir toda a comunicação a uma crosta uniforme e homogénea" (p. 61), Calvino sublinha o contraste entre o caráter avaro da riqueza do tempo no quotidiano e a sua pujança generosa na literatura, lugar onde os leitores dele podem dispor à vontade, fruindo um tempo "(...) que passa sem outra intenção que não seja a de deixar os sentimentos alicerçarem-se, amadurecerem e libertarem-se de toda a impaciência e de toda a contingência efémera" (CALVINO, 2006, p. 70). Isto é, alimentando "(...) demoras em que não se perde tempo" (ECO, 2019, p. 83).

No que respeita à "exatidão," importa destacar o que entendemos como movimentos de bondade que, em nosso entender, Calvino incute nos

\footnotetext{
${ }^{3}$ Esta última, conforme indicado na edição que utilizamos, foi extraída dos manuscritos preparatórios das "Norton Lectures," tratando-se "(...) da elaboração, provisória mas completa, da conferência inicial" (CALVINO, 2006, p. 147).

${ }^{4}$ Calvino faz menção a De rerum natura, de Lucrécio, e às Metamorfoses, de Ovídeo.
} 
modos como encara a linguagem, ao chamar a atenção para os cuidados de que deve revestir-se o seu uso, alertando para o que vê enquanto "(...) tendência para nivelar a expressão nas fórmulas mais genéricas, anónimas e abstratas, para diluir os significados, para embotar os pontos expressivos, para apagar toda a centelha que crepite ao encontro das palavras com novas circunstâncias" (CALVINO, 2006, p. 74). Talvez por essa razão, o primado da exatidão seja encarado enquanto abertura de aproximação às coisas, revelando-se no exercício da linguagem cujo caráter lacunar e fragmentário "(...) diz sempre menos em relação à totalidade do experimentável" (CALVINO, 2006, p. 92). ${ }^{5}$

No âmbito de tal abertura de mundos do nosso quotidiano a que aludimos, pode também ser entendida a relevância da "visibilidade" enquanto valor a salvar, para que possa ser acolhido o poder de "pensar por imagens" (CALVINO, 2006, p. 112), destrinçando o que ganha relevo no seu bombardeio hodierno, em que vamos participando. A implementação de uma pedagogia da imaginação, promovendo o mergulho reiterado na multiplicidade do redesenho da imagem para cada um, é, pois, encarada como um imperativo, dado poder possibilitar descobertas enriquecedoras sobre outras formas de morar na leitura, desdobrando-a.

À luz do anteriormente exposto se compreende, também, a defesa do valor da "multiplicidade", enquanto fio condutor alimentado ao longo do tempo, na consciência aguda da existência de uma rede sempre inacabada "(...) que liga todas as coisas" (CALVINO, 2006, p. 132) pois, "Cada vida é uma enciclopédia, uma biblioteca, um inventário de objetos, um catálogo de estilos onde tudo pode ser continuamente remexido e reordenado de todas as maneiras possíveis" (CALVINO, 2006, p. 145).

Em estreita conexão com o anteriormente exposto se compreende, com demoras, a conferência "Começar e acabar," ao ser sublinhado que "O início é um lugar literário por excelência porque o mundo lá fora é contínuo, não tem limites visíveis" (CALVINO, 2006, p. 150). Nesse sentido, é destacado o facto de a vida ser um tecido contínuo, o que, na literatura, se pode traduzir em opções de liberdade temporal cuja legitimidade não é posta em questão. Nas revisões de inícios e de reinícios que esta conferência de Calvino contempla, encontramos mundos múltiplos que convivem numa "(...) poeira de possibilidades que se agregam e desagregam" (CALVINO, 2006, p. 166), em harmonia.

Consideramos que o livro-álbum contemporâneo pode convocar o caráter multifacetado que Calvino (2006) espelha na sua visão do mundo, conglomerada nos valores da literatura a que antes aludimos. O caráter camaleónico do primeiro, nas múltiplas dimensões que tem vindo a assumir,

\footnotetext{
${ }^{5}$ Manteve-se o uso do itálico no original que aqui se reproduz. Semelhante critério é seguido ao longo do artigo.
} 
a forma como apela aos leitores (pela miríade de opções editoriais que têm à sua disposição), bem como o aprimoramento estético, constituem, hoje, inesperados modos de fruição na leitura que multiplicam redescobertas de mundos. Em tais indagações, a importância renovada concedida à abordagem de temáticas enraizadas no cuidado de aliar a Natureza aos leitores (por exemplo, MELÃO, 2019; RAMOS \& RAMOS, 2011), de modo belo e intenso, tem permitido realizar uma reflexão mais aprofundada sobre os pilares da sustentabilidade ambiental, no quadro dos objetivos globais para o desenvolvimento sustentável, desdobrando a sua compreensão. Para tal muito têm contribuído, também, propostas editoriais contemplando a redescoberta da Natureza, associando-lhe matrizes não ficcionais com tonalidades estéticas de grande qualidade (por exemplo, DIAS \& ROSÁRIO, 2016; GUTIÉRREZ, 2019; MARTINS, 2015).

\section{OBJETIVOS E METODOLOGIA}

Os objetivos que norteiam esta reflexão são os seguintes: i) desvelar modos de repensar a "multiplicidade" nas duas obras que constituem a matéria-prima da análise levada a cabo, descobrindo as suas possibilidades de reverberação na atualidade; ii) refletir sobre o modo como a Natureza e o livro-álbum formam um todo orgânico, estimulando a participação dos leitores, nas bermas que se vão tornando língua; iii) indagar percursos de valorização da sustentabilidade ambiental (PEDROSO, 2018; UNITED NATIONS, 2015), convocados pelo livro-álbum, nele se entretecendo.

De acordo com os objetivos traçados, as nossas opções metodológicas recaíram na realização de percursos de análise que, contemplando o caráter inusitado de cada um dos livros-álbum, possibilitassem convocar a relevância da participação ativa dos leitores nos processos de indagação abrigados na generosidade resultante da interação entre 0 texto e as ilustrações, profundamente promovida por Ondjaki/António José Gonçalves e Mia Couto/Danuta Wojciechowska.

A opção pela apresentação individual de cada percurso de leitura possibilita destacar a travessia de tonalidades plasmadas em cada livroálbum, valorizando a sua singularidade. No entanto, os itinerários propostos dialogam, de modo amplo, num processo de indagação mútua que se pretende tão vivaz quanto serenamente atento.

\section{PERCURSOS DE LEITURA}

\section{A água e a águia}

No mais recente livro-álbum que Mia Couto deu a lume, $A$ água e a 
águia(COUTO, 2018), com ilustrações de Danuta Wojciechowska, o escritor e ilustradora reencontram-se na demanda da criatividade enquanto processo multifacetado que pode congregar elementos da Natureza de forma versátil. A narrativa tem como pano de fundo o fluir do tempo que vai sendo filtrado através do jogo permanente envolvendo a transmutação, de diferentes formas, da vogal "i," na água que resolverá o facto de, um dia, a chuva se ter "esquecido" de "acontecer" (tendo como resultado uma situação de seca extrema).

No estudo de amplo escopo e profundidade que consagra a "leituras" de Mia Couto, Rothwell (2015) sublinha o seguinte:

Nos seus livros para crianças, as preocupações com a água, a escrita e o papel do sonho ganham lugar de primeiro plano, embora, em conformidade com as expetativas do seu público-alvo, o seu tratamento tenda a ser mais leve e mais positivo do que nos romances (ROTHWELL, 2015, p. 24).

A água e a águia (Couto, 2018), pelas características que reúne, embora possa ter como destinatário preferencial as crianças, propõe a todos os leitores modos de redescobrir a plurissignificação que reverbera na polissemia do conceito de sustentabilidade, ${ }^{6}$ possibilitando-Ihes rever 0 seu posicionamento perante os Outros - convocando o bem-estar e a proximidade enquanto entrelaçamentos de culturas entendidas, também, no plural.

\section{Narrativas dos peritextos entre caligrafias da Natureza}

O predomínio magnífico das sensações visuais e auditivas que permeiam este livro-álbum tem início na capa e na contracapa, reescrevendo-se no prolongamento do céu, terra e água que aí surgem representados. Mergulhar no azul ${ }^{7}$ e repousar nas nuvens pode ser poderoso refrigério, apelando ao investimento numa temporalidade sã, sem os constrangimentos da cronologia que os relógios - talvez avassaladoramente - hoje ditam: "Aconteceu quando não era ainda nenhuma vez (...) E o bater das asas era o único ponteiro do tempo" (COUTO, 2018, s/p). Como sublinha, em distinta reflexão, Mia Couto, "A literatura pode ajudar a criar um Tempo que concilie os tempos, uma identidade que nos reconcilie com os muitos seres que somos" (COUTO, 2019, p. 63).

\footnotetext{
${ }^{6}$ Vejam-se, por exemplo, a esse respeito, Sá, Lopes e Martins (2019) e Orr (2018).

7 Em outro lugar, Mia Couto recorda-nos que "(...) o azul nunca é uma cor exata. Apenas uma lembrança, em nós, da água que já fomos" (COUTO, 2016, p. 18). Sobre outros ecos, muito belos, do azul, mergulhese em Sonhos azuis pelas esquinas (ONDJAKI, 2014a).
} 
A proximidade entre a água e a águia é conseguida, na capa do livro, através da bela combinação do olhar que águia lança no título, onde as vogais " $u$ " e "i" se fundem e se alimentam da mesma cor, numa permuta harmoniosa que as destaca em permanência - "(...) toda a gente sabe, as letras igualam as estrelas: mesmo poucas são infinitas" (COUTO, 1991, p. 14).

O jogo com a paleta cromática das letras do título prolonga-se na página de rosto, cinzelando, desta feita as palavras "água" e "águia" (no primeiro caso, a verde, e no segundo caso, a azul), porventura num reflexo da comunhão entre os elementos da Natureza, perpetuada na partilha das cores mencionadas.

São múltiplos os detalhes que reconfiguram leituras da sustentabilidade, implicando, sobremaneira, os leitores. No exemplo que aduzimos a seguir encontramos um dos modos versáteis de os envolver nos movimentos da Natureza, na sua plenitude e quietude:

No fundo do vale corria um rio, o único rio que molhava as margens do mundo. As águias roçavam o seu leito e as asas, como remos, faziam ondear a água. E era tanto voo que as águas ficavam leves, tão leves que, por vezes, se erguiam do chão (COUTO, 2018, s/p).

Nos ecos de um tempo matizado de tempos que ganham voz no ondear da água proporcionado pelo suave movimento das asas das águias, os leitores podem escutar a leveza criada na escrita e os "prazeres da lentidão" a que alude Calvino (2006, p. 62), ${ }^{8}$ apelando a uma reflexão maior sobre como cultivamos, hoje, o tempo. Como sublinha Han (2016, p. 111):

A sociedade do consumo e do tempo livre apresenta uma temporalidade particular. O tempo que sobra, devido a um aumento de produtividade, é preenchido por acontecimentos e vivências superficiais e fugazes. Uma vez que nada liga o tempo de maneira duradoura, este parece correr muito depressa ou conhecer uma aceleração completa.

Nas palavras de Vergílio Ferreira (Ferreira, 2013) encontramos, também, o reforço da relevância de repensar, de diferentes formas, a rapidez que se coloca nos antípodas da quietude celebrada por Mia Couto:

Comemos ao balcão do nosso frenesim, corremos no

\footnotetext{
${ }^{8}$ Adicionalmente, a evocação de sensações que a língua ampara é reforçada pela ilustração cuja extensa luminosidade se destaca, em distintas tonalidades de laranja e de azul, expandindo o texto.
} 
alvoroço do nosso ser em febre, dormimos nos intervalos de estar sentado no autocarro da nossa velocidade. E lemos então no intervalo de dormir. Mas toda a nossa vida é feita de farrapos, de bocados, de duas sandes comidas no snack. Ou lemos durante, para mais depressa. Não lemos por inteiro, não pensamos por inteiro, não somos em nada tudo. Assim, em tudo nos falta o que não houve tempo de sermos e isso que nos falta é que era tudo (FERREIRA, 2013, p. 101).

A Natureza enquanto pródigo abrigo vai ressoando, a par e passo, na narrativa: "Tudo fluía e se trocava, céu e terra, asa e casa" (COUTO, 2018, $\mathrm{s} / \mathrm{p}$ ). A opção pela ilustração em dupla página possibilita ir dando fôlego ao protagonismo das águias que, nas suas asas, aconchegam aglomerados de casas, num movimento instigador de afetos que os leitores podem (a)colher.

$O$ retrato da seca que esculpe o fulcro da narrativa, em notório contraste com a harmonia que marcadamente ia fluindo, no seu começo, possibilita incutir ritmos distintos de fruição na leitura, pelos modos como implica os leitores numa lentidão pensada, com laivos de leveza que incitam à reflexão. A ilustração desempenha um papel preponderante nesse sentido, pela reconfiguração ampla da representação espacial, alimentando, por um lado, a empatia com a narrativa e abrindo, por outro, múltiplos espaços aos leitores para aí colherem a pluralidade impressa no inacabamento. A ampla generosidade que a ilustração potencia quando povoa de luz o olhar possibilita, por um lado, cultivar esse caráter inacabado e, por outro, como frisa Hoogslag (2019), regenera modos de interpretação da narrativa.

Tal inacabamento - que aponta caminhos aos leitores, - é conseguido através de múltiplas vias: i) pelos veios de plurissignificação que se entreabrem no uso multifacetado e atento da panóplia de cores que veste as ilustrações; ii) pelas inferências que resultam dos enquadramentos da ilustração na dupla página, motivando o incremento da compreensão na leitura; iii) pela repetição de pormenores relativos aos movimentos do redesenho das vogais que acentuam a relevância da "impalpável poeira das palavras" (CALVINO, 2006, p. 93), em que podemos também ler o entendimento de Mia Couto de que tudo flui (embora nem sempre serenamente), por entre os espaços em que o rio desagua na vogal "i."

À luz do referido se expandem, também, outros modos de reler o mundo, compreendendo o que Mia Couto designa "caligrafia da Vida" (COUTO, 2018, s/p). Esta é apresentada em três tempos que se unem e se fundem, de forma harmoniosa, para que seja resolvida a seca que assola 0 mundo: i) a mais velha das águias "(...) foi ao seu nome e devorou a letra 
"i." De imediato a palavra águia se converteu em água. E ave bebeu daquela água" (COUTO, 2018, s/p) - da repetição deste ato pelas outras águias resulta, apenas, uma solução precária; ii) as águias começaram a comer o "i" do próprio rio - e água foi desaparecendo, pois "Não sabiam que um rio nasce no r e desagua no o. Entre a nascente e a foz deve haver uma vogal costurando princípio e fim" (COUTO, 2018, s/p); iii) a mais velha das águias decide devolver as vogais "i" ao rio: "E eram letrinhas, trémulas e aflitas, costuradas umas nas outras como missangas de um mesmo fio (...) uma corrente de iis turbulenteou as margens e as águas se engravidaram de águas, em tantas e tantas ondas" (COUTO, 2018, s/p).

A regeneração da Natureza, ao passar pela "devolução" dos "iis," coloca a ênfase na relevância da manutenção de um todo orgânico cuja sustentabilidade se nutre intrinsecamente do respeito pela Terra - em movimentos de compromisso com a cidadania que a língua reescreve e amplia, ganhando outros rumos que recobrem todo o livro-álbum e se vão desenhando, sempre,

(...) em linhas uniformes de caracteres minúsculos ou maiúsculos, de pontos, de vírgulas, de parêntesis; páginas de sinais alinhados, densos e apertados, como grãos de areia representam o espetáculo variegado do mundo numa superfície sempre igual e sempre diferente, como as dunas impelidas pelo vento do deserto (CALVINO, 2006, p. 119)

Do exposto nesta seção do artigo, podemos, adicionalmente, inferir que, ao longo da narrativa ecoam alguns dos princípios definidos pelas Nações Unidas no que respeita à promoção de um novo paradigma para viver em Harmonia com a Natureza (UNESCO, 2017), numa partilha de responsabilidades em áreas de importância crítica para a humanidade e para o planeta (UNITED NATIONS, 2015). Como sublinha Couto, "A literatura confirma como somos parentes e próximos na nossa infinita diversidade" (COUTO, 2019, p. 91).

\section{O convidador de pirilampos}

O convidador de pirilampos (ONDJAKI, 2017), com ilustrações de António Jorge Gonçalves, integra-se no tríptico designado "Estórias sem luz elétrica", do qual fazem igualmente parte $A$ bicicleta que tinha bigodes (ONDJAKI, 2014b) e Uma escuridão bonita (ONDJAKI, 2015), obras que desvelam aos leitores aprendizagens do silêncio da demora, no acontecer do sonho. A narrativa constrói-se através dos itinerários de descobertas de um menino e do seu Avô ${ }^{9}$ na "Floresta Grande,"10 iluminando os medos do

\footnotetext{
${ }^{9}$ Respeita-se a opção de Ondjaki pelo uso de maiúsculas.

${ }^{10}$ Respeita-se a opção de Ondjaki pelo uso de maiúsculas.
} 
escuro do primeiro, bem como a sua insaciável curiosidade, e retratando os elos perenes de amor entre ambos. Os leitores podem ir paulatinamente ganhando alento nas "estórias"11 que a Natureza vai contando, iluminada pelos pirilampos - irreverentes, sábios e guardiões da oralidade que não se quer perdida.

\section{Trilhos (de leituras) da Natureza}

À semelhança do sucedido no seu último livro de poemas, Há gente em casa (ONDJAKI, 2018), no qual o amarelo que afaga a capa e a contracapa do livro o envolve em ampla luminosidade, $O$ convidador de pirilampos (ONDJAKI, 2017) guarda-a no título (destacado na capa) mas também nos pequenos pontos de luz que cintilam na escuridão da noite retratada. De realçar que, na página de rosto, o subtítulo "Estórias sem luz elétrica" exibe a mesma luz que progressivamente se estenderá e incidirá na escuridão partilhada com os leitores.

Quando se inicia a narração, o vasto céu, onde "brilham penduradas as estrelas, pequenas e belas," é uma tela que se amplia de distintos modos, através das ilustrações, possibilitando acentuar a vulnerabilidade de um menino e do seu Avô, face a tal imensidão. Nas cumplicidades que se vão alimentando entre ambos, desenhadas em espaços onde o branco estimula sobremaneira a atenção dos leitores, refletem-se formas de acolhimento do Outro e lançam-se desassossegos sobre caminhos de entendimento que vão reconstruindo "modos de apalpar a polpa da língua" (ONDJAKI, 2009, s/p).

Convoquemos Jorge Luís Borges que, em Atlas (BORGES, 2018, p. 78), refere o seguinte:

Não há um só homem que não seja um descobridor. Começa por descobrir o amargo, o salgado, o côncavo, o liso, o áspero, as sete cores do arco-íris e as vinte e tal letras do alfabeto; passa pelos rostos, os mapas, os animais e os astros; conclui pela dúvida ou pela fé e pela certeza quase total da sua própria ignorância.

Redescobertas de mundos que, em nosso entender, se inscrevem na reinvenção da língua que um dos verbos reescritos na narrativa "Cientistar" - conglomera: "Cientistar é o que nós, os cientistas e inventores, fazemos. Cientistamos as coisas, os animais, e alguns até cientistam o mundo" (ONDJAKI, 2017, s/p). Atentemos em algumas invenções que se acomodam, com propriedade, nesta definição, na ótica do menino: i) um "aumentador de caminhos" que permite "andar um pouco

\footnotetext{
${ }^{11}$ Como refere Ondjaki (2014b, p. 7): "(...) nessa letra "e" - minúscula e tão gigante - cabem os desejos
} e as fantasias feitos memória quase verdadeira." 
mais" a quem, na floresta, julga que chegou a um lugar sem saída e ir "inventando caminho até chegar onde quer;" ii) um "unóculo" que serve "para ler o brilho dos pirilampos," desvelando o que comunicam e iii) um "convidador de pirilampos" - pequena caixa que, em conjugação com os outros dois objetos, tem como objetivo atrair os pirilampos para o seu interior. Nas bermas da língua em que as invenções do menino encontram morada, lemos parte relevante do labor de quem (re)escreve, pois, como nos explica Mia Couto, "(...) o escritor usa uma língua dentro da língua, uma pátria que ele inventa não para viver, mas para sonhar. Ele não se serve da língua, o criador literário é inventado pela língua" (COUTO, 2013, p. 183).

Esta é, porventura, uma das missões felizes deste livro: mostrar, paulatinamente, aos leitores, a importância de "olhar as coisas" demoradamente. Tal ocorre, sobretudo, por duas vias, que confluem nas bermas da dupla página, de modo harmonioso: i) através das ilustrações de António Jorge Gonçalves; ii) "entre" os diálogos rodeados de afetos, tendo como protagonistas o Avô e o menino. No que se refere às primeiras, estas desempenham um papel fundamental relativamente à compreensão da aprendizagem das leituras propiciadas pela Natureza, nos seus contrastes de luzes e sombras e nos seus apelos a uma língua outra que é dada a conhecer pela "voz" dos pirilampos. Os segundos interagem com as primeiras, de forma harmoniosa, incrementando tal aprendizagem e potenciando outras, fundadas em laços entre gerações, aí desvelados.

Numa primeira instância, as ilustrações inscrevem os leitores numa representação espácio-temporal que ganha dimensão maior quer pelo contraste entre a escuridão e a luz, quer pelas invenções do menino que aí ganham corpo e movimento. Paulatinamente, ao longo da narrativa, como sublinhamos mais adiante, vão adquirindo relevo acrescido, mormente quando ecoam a musicalidade implícita na transcrição luminosa da "língua" dos pirilampos, tamborilando no compasso do código Morse.

As silhuetas do Avô e do neto, surgindo repetidamente recortadas no escuro, possibilitam enfatizar os desdobramentos implicados no labor de "olhar as coisas," apontado pelo menino como missão maior do cientista. Tal sucede, por exemplo, i) quando o Avô observa, com atenção, o "aumentador de caminhos" inventado pelo neto; ii) quando ambos, simultaneamente, se munem do "unóculo" para relerem o brilho dos pirilampos; iii) quando uma explosão de luz, matizada de cores fortes, eclode no "convidador de pirilampos," proporcionando aos leitores vivenciar a dança de cores que a sequência verbal que as acompanha não consegue conter.

Os diálogos entre o menino e o seu Avô merecem especial cuidado pelas diferentes formas como dão a conhecer momentos de fruição temporal e sensorial que, hoje, primam, porventura, por maior ausência, 
em culturas ditadas pelos ecrãs ${ }^{12}$ e consequente aceleração daí resultante nos nossos quotidianos. Numa primeira instância, ao mostrar as suas invenções ao Avô, é vincado que este tirava do bolso "(...) o seu velho canivete para depois comer uma laranja cheirosa" (ONDJAKI, 2017, s/p). Mais adiante na narrativa, este detalhe assume maior relevo, importando atentar no seguinte diálogo:

- Avô, eu adoro o cheiro da laranja na tua mão e no teu canivete.

- Porquê?

- Porque quando chego a qualquer lugar ... ou me aproximo de qualquer coisa que cheire a laranja ... é como se estivesses perto, a conversar comigo (ONDJAKI, 2017, $\mathrm{s} / \mathrm{p}){ }^{13}$

Como sublinha Han (2016, p. 61), "O aroma está, de certo modo, carregado de histórias. Compõe-se de histórias, de imagens narrativas (...) $\mathrm{O}$ aroma é lento. Por isso, não se adequa, nem mesmo de uma perspetiva medial, à época da pressa." As palavras do menino alimentam um efeito de duração que excede o caráter linear do tempo que hodiernamente nos é imposto, reabrindo uma fruição rara do momento vivido (e deixando aos leitores tal apelo).

A importância de conceder atenção a tudo o que nos rodeia, tendo tempo para o pormenor, é particularmente frisada num dos diálogos entre o Avô e o menino, cabendo a este último explicitar que "Os cientistas parecem malucos porque passam muito tempo a olhar as coisas e às vezes olham coisas que os outros não conseguem ver. Porque há pessoas que olham sempre a ver muito pouco!" (ONDJAKI, 2017, s/p).

Merecem também destaque as aprendizagens mútuas entrelaçadas nos diálogos de ambos, na medida em que acolhem a compreensão das repercussões das atitudes humanas no que à Natureza diz respeito. Tal fica bem ilustrado na perspetiva distinta que é apresentada relativamente ao "convidador de pirilampos," criado pelo menino. A questão colocada pelo seu Avô - "Não achas que podem ficar tristes, esses pirilampos, dentro de uma gaiola que fica dentro do teu quintal? (ONDJAKI, 2017, s/p), reiterando, logo a seguir, que os pirilampos podem estar a brilhar de tristeza, convida a uma reflexão maior sobre distintos modos de escutar o mundo, em todas as suas complexidades. Como bem sublinha Sacristán

12 Vejam-se, a esse respeito, Martins, 2017 e Cardoso, 2013.

${ }^{13}$ Note-se como anteriormente, em outro lugar, Ondjaki concedera relevo à aliança perene do aroma à memória: "Ainda bem que os cheiros ficam bem presos na nossa memória das recordações. Eu acho que, quando formos crescidos, vamos gostar de reencontrar estas coisas do nosso antigamente" (ONDJAKI, 2015, p. 91). 
(2003, p. 56): "Somos únicos e, ao mesmo tempo, somos semelhantes aos outros, porque, ainda que partilhemos características com eles, possuímolas de forma singular. A peculiaridade e a especificidade da individualidade é a primeira causa da diversidade cultural."

Na segunda parte da narrativa, marcada pelo diálogo entre o menino e os pirilampos, oralidade e luz vão-se entretecendo enquanto todo orgânico, imbricando-se na natureza perene dos recomeços. O desvendar do que o Avô do menino apoda de "código dos pirilampos" (que o neto lhe assegura ser parecido ao código Morse, o que lhe possibilita compreender o que "dizem"), permite pôr a nu a distinção entre os "pirilampos cintilantes" e os "pirivelhos" - contadores das estórias muito, muito antigas" - mostrando a importância de formas renovadas de encarar a oralidade enquanto valor intemporal que se demora na Natureza e com ela estabelece laços de sustentabilidade (cujo equilíbrio e reforço é da responsabilidade de todos). Para tal aponta, também, o ensinamento de um dos pirilampos: "as estórias não são de ninguém. São da Floresta Grande. São do tempo," interligando gerações e preservando o seu legado.

O ciclo de recomeços permanentes que os leitores vão reencontrando, também, nos diálogos entre a narrativa e as ilustrações, fica impresso nas palavras do menino que promete ficar em casa "(...) a ler janelas...quer dizer, eu estarei na minha janela a ouvir as vossas estórias" (ONDJAKI, 2017, s/p) - deixando patente a importância de escutar a Natureza mas, sobretudo, as leituras da escuta que esta pode ampliar, tendo como fio condutor a oralidade.

No "final" da narrativa, o "convidador de pirilampos" ganha lugar cativo na Floresta Grande, envelhecendo com ela. Caberá, desta feita, a um "pirivelho" contar aos pirilampos cintilantes a estória do menino que "cientistava pirilampos" e do seu Avô: "Perto da nossa floresta grande havia uma casa, onde vivia um menino e o seu avô e os eu canivete e as suas laranjas. Era em menino muito curioso que cientistava pirilampos. $\mathrm{E}$ que aprendeu a ser amigo do escuro" (ONDJAKI, 2017, s/p). A voz do "pirivelho" confere alento à narrativa e reinicia-a; e os leitores, aportam, de novo, nas "bermas da língua" que Ihes reabrem a possibilidade de compreender que "(...) precisamos de recomeçar sempre e sempre" (COUTO, 2013, p. 136) e de cultivar a morosidade do instante.

\section{CONCLUSÕES}

"As línguas e as culturas fazem como as criaturas: trocam genes e inventam simbioses como resposta aos desafios do tempo e do ambiente" (COUTO, 2013, p. 18). As duas narrativas analisadas facultaram matériaprima para fazer sobressair tais desafios, podendo ser entendidas enquanto 
lugares privilegiados para os repensar face aos modos como, de forma diversificada e ampla, os expõem diante dos leitores.

$A$ água e a águia (COUTO, 2018), na generosa oferta da permuta de vogais buriladas na Terra, reapresenta a Vida aos leitores, em distintas metamorfoses que fluem no texto e nas ilustrações. Nos caminhos que reabre, nomeadamente nos limiares da língua que olhos e mãos perscrutam e tocam, este livro-álbum possibilita incrementar, de modo intenso, a empatia com a Natureza - conciliando gestos entre gerações que reúnem afetos.

Os percursos de leitura entrelaçados no livro-álbum $O$ convidador de pirilampos (ONDJAKI, 2017) permitiram, por seu turno, lançar luz sobre o caráter indelével das estórias, omnipresente nas relações quotidianas que construímos. Assumindo facetas de perenidade inabalável, os elos entre um avô e um neto transbordam das páginas que os pirilampos iluminam, resguardando-se em instantes de fruição (doces memórias).

Nas duas obras, os leitores reencontram modos de repensar a "multiplicidade," podendo erguer um posicionamento indagador sobre a vivência hodierna do tempo, nas suas diversas facetas. Tal reflexão revelase, a nosso ver, como percurso fundamental que espelha o que podemos e queremos ser enquanto tecemos futuros.

Através da releitura do conjunto de valores da literatura propostos por Calvino (2006), os itinerários que percorridos permitiram, por seu turno, lançar luz sobre a relevância do livro-álbum na demanda pela atenção ao detalhe que a escuta da Natureza exige e reclama - condição atualmente indispensável à nossa sobrevivência, na leitura que fazemos relativamente à relevância do cumprimento dos objetivos no âmbito da Agenda para o desenvolvimento sustentável que nos implicam na construção do bem comum.

Ensinando-nos que "Assim como nós criamos as línguas, também as línguas nos criam a nós" (AGUALUSA, 2010, p. 59), as vozes de Mia Couto e de Ondjaki, plasmadas ao longo do artigo, reconfiguram um convite perene a que os tempos das "estórias" possam ser o argumento sustentador de um bem-estar conciliador da "multiplicidade" - repousando na luz que as consoantes e as vogais acolhem e nelas continuando a reescrever-se pela língua fora. Em tais tessituras deambula, também, a poesia, sopro de alentos que verseja ao longo das duas narrativas. Nas suas travessias, despertam, porventura, manhãs que proclamam que "A poesia não está somente nos versos, por vezes ela está no coração, e é tamanha, a ponto de não caber nas palavras" (AMADO, 2020, p. 78). 


\section{REFERÊNCIAS}

AGUALUSA, José Eduardo. Milagrário pessoal, 3 ed. Alfragide: Publicações D. Quixote, 2010.

. Estranhões \& Bizarrocos. Estórias para adormecer anjos. Ilustrações de Henrique Cayatte. Alfragide: Publicações D. Quixote, 2000.

AMADO, Jorge. 0 gato malhado e a andorinha sinhá, 26. ed. Leya: Alfragide, 2020.

BORGES, Jorge Luís. Atlas. Tradução de Fernando Pinto do Amaral. Lisboa: Quetzal Editores, 2018.

CALVINO, Italo. Seis propostas para o próximo milénio, 5. ed. Tradução de José Colaço Barros. Lisboa: Editorial Teorema, 2006.

CARDOSO, Gustavo. A sociedade dos ecrãs. Lisboa: Tinta-da-China, 2013.

CAVACAS, Fernanda. Mia Couto. Um moçambicano que diz Moçambique em português. Lisboa: Clássica Editora, 2015.

COUTO, Mia. 0 universo num grão de areia. Lisboa: Caminho, 2019.

. A água e a águia. Ilustrações de Danuta Wojciechowska. Lisboa: Caminho, 2018.

. Um rio chamado tempo, uma casa chamada terra, 7. ed. Lisboa: Leya, 2016.

E se Obama fosse africano? Interinvenções, 3. ed. Lisboa: Caminho, 2013.

Cronicando. Lisboa: Caminho, 1991.

DIAS, Maria Ana Peixe; ROSÁRIO, Inês Teixeira do. Lá fora - guia para descobrir a natureza. Ilustrações de Bernardo P. Carvalho. 3. ed. Carcavelos: Planeta Tangerina, 2016. ECO, Umberto. Seis passeios nos bosques da ficção. Tradução de Wanda Ramos. Lisboa: Gradiva, 2019.

FARIA, Daniel. O livro do Joaquim. Lisboa: Assírio \& Alvim, 2019.

FERREIRA, Vergílio. Pensar. Lisboa: Quetzal Editores, 2013.

GENETTE, Gérard. Seuils. Paris: Seuil, 1987.

GUTIÉRREZ, Xulio. Viajantes, animais extraordinários. Ilustrações de Nicolás Fernández. Matosinhos: Kalandraka, 2019.

HAN, Byun-Chul. O aroma do tempo. Tradução de Miguel Serras Pereira. Lisboa: Relógio D’Água Editores, 2016.

HOOGSLAG, Nanette. How illustration works: exploring a model of editorial illustration in print and online media. In: MALE, A. (Ed.) A companion to illustration. New Jersey: John Wiley \& Sons, 2019, p. 277-304.

MARTINS, Isabel Minhós. Um ano inteiro - almanaque da natureza. Ilustrações de Bernardo P. Carvalho. Carcavelos: Planeta Tangerina, 2015.

MARTINS, Moisés de Lemos. Crise no castelo da cultura - das estrelas para os ecrãs, 2. ed. Vila Nova de Famalicão: Húmus, 2017.

MELÃO, Dulce. "Rio Acima" - travessias da ilustração no livro-álbum e ecoliteracia, CONFIA 2019. 7th International Conference on Illustration and Animation. Barcelos: Instituto Politécnico do Cávado e do Ave, 2019, p. 427-435.

MICHELETTI, Everton Fernando. A palavra viva de Mia Couto. Estudos Linguísticos, 46 (3), p. 1167-1179, 2017. Disponível em: https://revistas.gel.org.br/estudoslinguisticos/article/viewFile/1630/1283. Acesso em: 14 set. 2019.

ONDJAKI. 0 convidador de pirilampos. Ilustrações de António Jorge Gonçalves. Lisboa: Editorial Caminho, 2017.

. Uma escuridão bonita, 3. ed. Ilustrações de António Jorge Gonçalves. Lisboa:

Editorial Caminho, 2015.

. Sonhos azuis pelas esquinas. Lisboa: Caminho, 2014a.

. A bicicleta que tinha bigodes, 3. ed. Ilustrações de António Jorge Gonçalves.

Lisboa: Editorial Caminho, 2014b.

ORR, David. Dangerous years. Climate change, the long emergency, and the way forward. Yale University Press, New Haven and London, 2018. 
PEDROSO, José Vítor (Coord.). Referencial de educação ambiental para a sustentabilidade. Lisboa: Ministério da Educação, 2018.

RAMOS, Ana Margarida; RAMOS, Rui. Ecoliteracy through imagery: a close reading of two wordless picture books. Children's Literature in Education, 42, 325-349, 2011.

ROTHWELL, Philip. Leituras de Mia Couto. Aspetos de um pós-modernismo moçambicano. Coimbra: Almedina, 2015.

SÁ, Patrícia; LOPES, José Bernardino; MARTINS, Isabel. Sustentabilidade e intercompreensão: perspetivas e contributos de um centro de investigação em educação. Revista Lusófona de Educação, 43, 91-97, 2019.

SACRISTÁN, José Gimeno. Educar e conviver na cultura global. Porto: Edições Asa, 2003.

SILVA, Sara Reis da. Entre textos. Perspetivas sobre a literatura para a infância e juventude. Porto: Tropelias \& Companhia, 2011.

SOUSA, Marta Noronha; ZAGALO, Nelson; MARTINS, Moisés de Lemos. "Eu também posso propagar histórias". A adaptação e as narrativas transmediáticas na era da participação. Comunicação e Sociedade, 22, 167-183, 2012.

UNESCO. Educação para os objetivos de desenvolvimento sustentável. Paris: UNESCO, 2017.

UNITED NATIONS. Transforming our world: the 2030 agenda for sustainable development. New-York: United Nations, 2015.

RECEBIDO EM: 29/11/2021

ACEITO EM: 07/12/2021 


\title{
EXÍLIO E SENTIMENTO NA CIDADE EM "LAS VENTANAS SE HAN ESTREMECIDO', DE CÉSAR VALLEJO
}

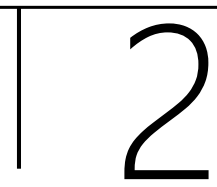

\section{EXILE AND FEELING IN THE CITY IN "LAS VENTANAS SE HAN ESTREMECIDO' BY CÉSAR VALLEJO}

\begin{abstract}
LANNOY, Lucie Josephe de
Doutora em Literatura. Professora Adjunta de Língua Espanhola junto ao Departamento de Línguas Estrangeiras e Tradução, do Instituto de Letras da Universidade de Brasília, no Distrito Federal.

E-mail:

ORCID ID:
\end{abstract}

\section{BARBOSA, Sidney}

Doutor e Língua e Literatura Francesa. Livre-Docente, Professor Associado de Literatura Francesa junto ao Departamento de Teoria Literária e Literaturas da Universidade de Brasília e docente do Programa de PósGraduação em Literatura da mesma Universidade. Líder do Grupo Interinstitucional de Pesquisa TOPUS, dedicado ao estudo do espaço na Literatura e em outras artes e do LiterArtes, consagrado ao estudo das relações entre Literatura e outras artes.

E-mail: sidneyb@unb.br

ORCID ID: https://orcid.org/0000-0001-8976-563X

\section{RESUMO}

O poema "Las ventanas se han estremecido" ("As janelas estremeceram") faz parte da obra do poeta peruano César Vallejo (1892-1938) Poemas Póstumos I, também chamados Poemas Humanos ou Los poemas de París. A análise, realizada segundo $A$ poética do espaço, de Gaston Bachelard (1884-1962), e as próprias reflexões do poeta, registradas em artigos e crônicas, contemplam uma relação ambígua do autor com a cidade do seu exílio, Paris. É a partir desse espaço, no entanto, que o artista toma consciência de aspectos culturais e sociais da América Latina e os apresenta traduzidos sensorialmente em sua poesia.

Palavras-chave: Poesia peruana; espaço na poesia; César Vallejo; escrita do exílio; poesia moderna.

\section{ABSTRACT}

The poem "Las ventanas se han trembled" ("The windows were shaken") is part of the work of the Peruvian poet César Vallejo (1892-1938) Poemas Póstumos I, also called Human poems or The Poems of Paris. The analysis was carried out according to Gaston Bachelard's (1884-1962), The Poetics of Space and the poet's own reflections, which come from his articles and chronicles, contemplating an ambiguous relationship between the author and the city of his exile, Paris. It is from this space, however, that the artist becomes aware of cultural and social aspects of Latin America 
and presents them translated in a sensorial way in his poetry.

Keywords: Peruvian poetry; space in poetry; César Vallejo; writing from exile; modern poetry.

\section{INTRODUÇÃO}

César Abraham Vallejo Mendoza (1938-1982), filho de Francisco de Paula Vallejo Benítez e neto do sacerdote espanhol da Galícia, José Rufo Vallejo e da índia Chimú, Justa Benítez e de María de los Santos Mendoza Gurrionero (filha também do sacerdote espanhol Joaquín de Mendoza e da índia Natividad Gurrionero), nasceu em Santiago de Chuco, na província peruana de La Libertad e foi o caçula de uma família de onze filhos. Segundo uma tradição espanhola que se aplicava parcialmente no contexto criolo, 0 filho mais jovem de uma família burguesa deveria tornar-se padre. Sendo o seu pai escrivão, aprendeu, desde cedo que escrever bem conferia autoridade e realização social. Desse modo, ainda que tendo uma infância em condições humildes, a cultura e a religiosidade do lugar impregnaram a sua formação. Vallejo estudou em Trujillo, capital da Província e, na época da conclusão dos estudos, escreveu uma tese sobre o Romantismo. Nesse período (1919$1920)^{14}$, o Peru vivia um momento de mudanças políticas. Em uma visita que o poeta fez a sua família houve um levante popular e ele foi acusado pelas autoridades de ser o mentor da revolta, sendo preso, injustamente, por cento e vinte dias. Nesse período, ele escreveu a obra Trilce (1922), uma obra que pode ser considerada de vanguarda, tanto pela forma como pelo conteúdo. Mas, como consequência desses problemas políticos exila-se na França.

É nesse contexto que Vallejo parte do Peru para, sem o saber ou desejar, nunca mais voltar. Será difícil para ele abrir um caminho à força de aventurar-se no desconhecido. A sua vida na Cidade-Luz o expõe ainda mais à pobreza, quase à miséria. Porém, os desafios farão dele também um ser comprometido com o destino do seu país e solidário com as causas do povo espanhol na Guerra Civil, incorporando-as à sua própria escrita. E se a sua obra mais inovadora fora Trilce, produzida no sofrimento e na injustiça de sua terra, será em Paris que ele realizará até o fim aquele destino prenunciado por seu amigo Orrego ${ }^{15}$, o de amadurecer 0 estilo e a expressão poética e criar valores e propostas estéticas pessoais.

\footnotetext{
${ }^{14}$ Nesse período, destaca-se o governo de Augusto B. Leguía e as disputas intestinas do Estado peruano passam por um golpe e pela promulgação da Carta Magna de 1929.

${ }_{15}$ Orrego, Antenor (apud: Candela, G.P. El proceso Vallejo, Trujillo: Universidad Nacional de Trujillo, 1992: 13).
} 


\section{ANÁLISE DO POEMA}

César Vallejo chega a Paris, em julho de 1923, sem saber falar francês e desempregado. Durante dois anos tem problemas para se manter e, provavelmente, por padecer diversas necessidades, adoece. Em 24 de março de 1924 , recebe a notícia do falecimento de seu pai. Essa dolorosa notícia, somada à sua má alimentação e às angústias econômicas, provocou-Ihe uma crise nervosa (VIGIL, 2005). Em outubro daquele ano, adoece gravemente e é operado de hemorragia intestinal no Hospital de la Charité.

Essa experiência pessoal dolorosa e melancólica está registrada no poema "Las ventanas se han estremecido", o qual apresenta cento e dez versos livres com variado número de sílabas métricas (versos anisossílabos). O texto alude, de modo geral, ao hospital e se relaciona à vivência do próprio Vallejo, que compartilhou um dos quartos com outros doentes. O tema da autobiografia em Poemas Humanos é raro e serve apenas como ponto de partida para expressar, no caso deste poema, "quão doloroso é ter que morrer de costas para os homens" (REYNOLDS, 1970):

Las ventanas se han estremecido, elaborando una metafísica del universo. Vidrios han caído. Un enfermo

lanza su queja: la mitad por su boca lenguada y sobrante, y toda entera, por el ano de su espalda.

Es el huracán. Un castaño del jardín de las Tullerías habrase abatido, al soplo del viento, que mide ochenta metros por segundo. Capiteles de los barrios antiguos, habrán caído, hendiendo, matando.

¿De qué punto interrogo, oyendo a ambas riberas de los océanos, de qué punto viene este huracán, tan digno de crédito, tan honrado de deuda, derecho a las ventanas del hospital?iAy las direcciones inmutables, que oscilan entre el huracán y esta pena directa de toser o defecar!iAy! las direcciones inmutables, que así prenden muerte en las entrañas del hospital y despiertan células clandestinas, a deshora, en los cadáveres.

(...) (VALLEJO, 1996, p. 312).

Este poema inicia-se com um tema semelhante ao do poema I, da obra Trilce: 
QUIÉN HACE TANTA bulla y ni deja

Testar las islas que van quedando.

Un poco más de consideración

(...)

Y el mantillo líquido, seis de la tarde

DE LOS MÁS SOBERBIOS BEMOLES.

Y la península párase

Por la espalda, abozalada, impertérrita

En la línea mortal del equilibrio.

VALLEJO, 1996, p. 170).

Afinal, estar em um quarto de hospital é, de certa forma, como estar no isolamento de uma prisão. Segundo a Poética do espaço (BACHELARD, 1974), pela explosão de uma imagem (como a das janelas que estremeceram ou a dos vidros que caíram devido a um estrondo), o passado longínquo (o da prisão de Vallejo) ressoa em ecos e não se pode mais discernir até onde se trata da repercussão daquela experiência ou se inicia uma nova. As linguagens dos dois poemas seguem projetos diferentes. Contudo, ambos fazem alusão ao barulho de uma eliminação de gases intestinais. Em Trilce, o tema abrange todo o poema. Já, nesse longo poema, sugere-se isso apenas nas quatro primeiras estrofes.

Ao relacionar este fato com Paris, observa-se que há barulho também na cidade, devido a um "furacão". Paris figura como metáfora pela qual os "capitéis" que caem equivaleriam ao excremento defecado. Contudo, o que fala mais alto no poema não é nem a flatulência e nem o furacão, mas um lamento. Há um reclamo: "iAy! las direcciones inmutables!", em um tom que expressa desejo de mudança. No poema entram em choque frontal os dois espaços que colidem de forma a tornar possível essa mudança, realizando o desejo do poeta: assim como a árvore ou os capitéis dos bairros antigos, desabaram os vidros das janelas que estremeceram. 0 mundo interior (da clínica) e exterior (da cidade) unifica-se, tornando-se o próprio universo a habitação do poeta, pois "todo espaço verdadeiramente habitado traz a essência da noção de casa" (BACHELARD, 1974: 200). O espaço assim transformado torna-se a própria expressão da emoção do poeta.

Vallejo foi operado dos intestinos. E o eu lírico, em outra parte do mesmo poema, questiona-se:

¿Cuánto tiempo ha durado la anestesia, que llaman los hombres? iCiencia de Dios, Teodicea! isi se me echa a vivir en tales condiciones, anestesiado totalmente, volteada mi sensibilidad para adentro! iAh doctores de las sales, hombres de las esencias, prójimos de las bases!ipido se me deje con mi tumor de conciencia, con mi irritada lepra sensitiva, ocurra lo que ocurra, aunque me muera! Dejadme dolerme, si lo 
queréis, mas dejadme despierto de sueño, con todo el universo metido, aunque fuese a las malas, en mi temperatura polvorosa. (VALLEJO, 1996, p. 312).

Ele expressa toda a angústia que a possibilidade de ficar anestesiado Ihe causa, a ponto de pensar na morte. Ele compara a dor física com a dor psicológica ou moral. A anestesia serve para mitigar a dor física, mas se tiver que servir também para diminuir a dor moral, o poeta revolta-se: "ipido que me deje com mi tumor de conciencia!". Se a vida tem sentido, a dor também o terá: o poeta prefere que o deixem sofrer, "Dejadme dolerme" (...), mas/dejadme despierto de sueño, con todo el universo me-/tido, aunque fuese a las malas, em mi tempereatura polvo-/rosa." A escrita desse poema em prosa repercute até nos mínimos detalhes como a forma de separar as palavras. Quando o poeta escreve "polvorosa", será que o fez consciente do jogo de palavras ao separar "polvo" (pó) de "rosa" (rosa)? Todo esse imaginário colabora para habitar com um novo olhar o lugar onde está vivendo, por meio de uma dialética elaborada entre a realidade e a arte. Parece sugerir que o sentido da dor esteja no ficar acordado, com um sonho vivo, do qual comungam o poeta e o universo. Com a quebra dos vocábulos/versos, mormente em "polvo/rosa" Vallejo quebra não apenas o dualismo sintático/morfológico, mas ao mesmo tempo a cadeia sinestésica que transforma comparações, num primeiro nível, em plasticidade metafórica, ou seja, denuncia, nas palavras e pelas palavras, o contrapelo da língua: "polvo/rosa" converte-se em "polvo" "rosa" e ao mesmo pode-se ler "polvorosa" passando assim da dimensão orgânica animal - como o "eu" lírico do poema, despido do sentimento do mundo pela anestesia sinestésica dos sentidos humanos, em confronto com o que revelam as "janelas/ventanas" do sentido físico desse mundo que teima em ser orgânico/inorgânico. Desse modo, o poeta quebra essa dualidade reflexiva e o homem, triste animal doente e combalido pela ciência do mundo, volta a ser triste e combalido e de novo, como propunham as teses científicas daquele momento do poeta, a aporia duplica-se nesse corpo mundo e mundo corpo, porque não há mais comparações sinestésicas para igualar ou para passar de um universo a outro ou de uma imagem para outra. E é desse modo que a imagem do eu lírico amplificado no espaço fala no âmago do ser para o ser no seu âmago. Bachelard (1974. p.183-184), diz-nos que não é na causalidade mas na repercussão (retentissement) "que acreditamos encontrar as verdadeiras medidas do ser de uma imagem poética. Nessa percussão, a imagem poética terá uma sonoridade do ser. Será necessário, pois, para determinar o ser de uma imagem, senti-la em sua repercussão".

Bachelard (1974, p. 200) retoma essa dualidade de "habitações" e seus "cantos" como uma condição do homem no ser e do ser no homem, ou ainda do homem na cidade e da cidade no homem, ou ainda seus 
"aposentos":

É preciso dizer então como habitamos nosso espaço vital de acordo com todas as dialéticas da vida, como nos enraizamos, dia a dia, num "canto do mundo". Pois a casa é nosso canto do mundo. Ela é, como se diz freqüentemente, nosso primeiro universo. É um verdadeiro cosmos. Um cosmos em toda a acepção do termo. Até a mais modesta habitação, vista intimamente, é bela. Os escritores de "aposentos simples" evocam com freqüência esse elemento da poética do espaço. Mas essa evocação é sucinta demais. Tendo pouco a descrever no aposento modesto, tais escritores quase não se detêm nele. Caracterizam o aposento simples em sua atualidade, sem viver na verdade a sua primitividade, uma primitividade que pertence a todos, ricos e pobres, se aceitarem sonhar.

A imagem poética da cidade, do homem, do local, do aposento, em suma a "poética do espaço" é um reflexo dialógico do "sentimento do mundo", de Carlos Drummond de Andrade, e também daquela poesia enfincada nessas fratrias palavras de Ortega y Gasset:

Quando não há alegria, a alma se retira para um lugar de nosso corpo e faz dele seu covil. De quando em quando dá um doloroso uivo ou mostra os dentes para as coisas que passam. E parece que todas as coisas abrem caminho, sujeitas ao fardo de seu destino, e nenhuma tem vigor o bastante para dançar com ele sobre os ombros. A vida nos oferece um panorama de escravidão universal. Nem a trêmula árvore, nem a serra que incorpora vacilante seu peso, nem o velho monumento que perpetua em vão sua exigência de ser admirado, nem o homem, que, ande por onde ande, leva sempre o semblante de estar subindo uma encosta - nada, ninguém manifesta maior vitalidade que a estritamente necessária para alimentar sua dor e sustentar em pé sua desesperação.

$\mathrm{E}$, ademais, quando não há alegria, cremos fazer um atroz descobrimento. Muito especialmente se a falta de alegria provém de uma dor física percebemos com estranha evidência a linha negra que limita cada ser e o encerra dentro de si, sem janelas para fora, como dizia Leibniz, porém sem o infinito que esse homem feliz colocava dentro de cada um. Este é o descobrimento que fazemos por meio da dor como se fosse por meio de um microscópio: a solidão de cada coisa. (ORTEGA Y GASSET, 2013, p. 31) 
Vallejo não pode deixar a sua enfermaria e nem fazer menos do que sonhar e fazer sonhar. Cabe ao leitor, decidir de que universo se trata, segundo a atualidade da leitura. Após a experiência estética que nos transmite o poeta ao expressar a sua emoção que se expande para além dos muros do hospital, não apenas transforma-se o espaço que habita mas, o universo e a dor o levam a concluir o poema começando um diálogo com um Deus próximo, em forma de litania, repetindo três vezes a mesma estrofe que apenas mudará o tempo do verbo do presente para o passado no último verso: "que se pôde deixar na vida!:

iNo es grato morir, señor, si en la vida nada se deja y si en la muerte nada es posible, sino sobre lo que se deja en la vida!

(VALLEJO, 1996, p. 312).

Como já expressado por Reynolds (1970: 160), "a ideia de morrer sem realizar-se na vida, priva à própria morte de transcendência". Pois, de fato, se a vida tem sentido, terá sentido não só a dor, mas, também, a morte. Entretanto, ao relacionar a noção de transcendência com o Absoluto, a Verdade, Girardot (1996: 519) observa que, para Vallejo, "a Verdade não é Deus mas, um estado prévio da vida do homem que se perdeu". Segundo Vigil (2005: 22), ao poeta não Ihe interessam dogmas, preceitos de uma catequese teológica e nem uma crença cerebral abstrata. Ele está mais interessado na divinização do ser humano e deste mundo do que com a vida no além.

Entretanto, não se trata de pensar em Paris, onde viveu Vallejo nesse tempo de exílio, como uma cidade pouco acolhedora ou um lugar de provação, apenas. A relação de Vallejo com a Cidade-Luz é ambígua. Por um lado, o poeta sente-se renascer, como ele mesmo diz: "Percebo-me em um país estranho, no qual tudo ganha aspecto de nascimento, luz de epifania imarcescível ${ }^{16 "}$ (VALLEJO, 1996, p. 298). E, por outro lado, Franco (1996, p. 592) lembra que, outras vezes, Vallejo "observa uma cidade que se destrói, uma cidade não de luzes mas de janelas quebradas, de hospitais e de morte", como, de fato, ele o expressa no poema que analisamos, "As janelas estremeceram". Afinal, Paris proporciona-Ihe, por um lado, o contato com poetas, escritores, pintores, músicos latino-americanos e estrangeiros, o que enriqueceu o seu imaginário. Mas, por outro lado, Vallejo esteve, também, marginalizado pela sua pobreza.

Os anos 1930 foram, para o mundo do período entre guerras, extremamente desafiadores. Na condição de estrangeiro, Vallejo enfrentou

\footnotetext{
${ }^{16}$ Me advierto en un país extraño, en el que todo cobra relieve de nacimiento, luz de de epifanía inmarcesible. (VALLEJO, 1996, p. 298).
} 
árduas dificuldades. Porém, ele soube encontrar sentido e, por meio da arte e do seu engajamento, brindou ao mundo sinais de esperança. Paris será o palco no qual Vallejo ensaiará a sua poética do espaço, no sentido de servirse deste, como meio para expressar o seu lirismo. Os lugares que aparecem nas suas crônicas e poesias configuram símbolos por meio dos quais transforma a realidade. Ele cria uma linguagem capaz de inverter, por exemplo, a situação de estranhamento em um lugar familiar; na rua, espaço do anonimato, cria visibilidade; na distância, encontra a proximidade. $\mathrm{E}$, aos poucos, durante as viagens à União Soviética ou durante a Guerra Civil Espanhola, aperfeiçoará ainda mais essa arte: onde cidades bombardeadas ou campos de batalha, símbolos de injustiça e destruição, permeiam-se de uma ótica de solidariedade e abertura para um sentido novo.

Vallejo sofre e, ao mesmo tempo, observa a vida em Paris. E assim como ama a cidade, ele, com a óptica de quem já possui uma vivência em outros lugares, consegue descrever aspectos retrógrados da cultura, mas também se nutre da alegria de acompanhar a "loucura insubstituível da arte" (Caisso, apud Vallejo, 1994: 12). Ele parece interrogar-se sobre as possibilidades do destino humano, como dirá em um poema em prosa: "Hay, madre, un sítio en el mundo, que se llama París. Un sítio muy grande y lejano y outra vez grande" (Vallejo, 1996: 309, "Poema Póstumo I", El buen sentido).

Segundo Bachelard (1974: 200), se quisermos determinar a realidade profunda de cada um dos matizes de nossa atração por um lugar escolhido, quantos problemas conexos encontraremos. "Para um fenomenólogo, o matiz deve ser tomado como um fenômeno psicológico de primeira ordem. O matiz não é uma coloração superficial suplementar. É preciso dizer, então, como habitamos"

"Em Paris tudo é possível", torna a dizer algumas vezes o poeta. Segundo Caisso (op. cit.,p. 311), essa frase aparece em muitos textos - tais como: "O assassino de Barrès" (op. cit., p. 313, v. II), "A visita dos reis de Espanha a Paris" (op. cit., p. 247), "O crepúsculo das águias" (op. cit., p. 399), "Crônica de Paris" (op. cit., p. 187, v. I) - depois de criticar a frivolidade, de ter polemizado postulados de vanguarda, de ter hostilizado os ritos dos funerais ou indagado sobre a cultura. Ele observa a vida com uma mistura de admiração e desconfiança. Preocupa-se com a dimensão humana do homem comum. E adota, em relação a Paris, a postura de alguém que deve ouvir e aprender obedientemente de modo a poder reencontrar o prazer do filho junto à mãe, essa mãe cuja dimensão é totalizante, unânime com o desejo do filho de superar distâncias, unificar mundos, consolar-se. Pois, como diz Bachelard (1974: 201) "o verdadeiro bem-estar tem um passado". Em Vallejo está, certamente, relacionado à figura materna.

Há muitos poemas que fazem referência a Paris. Em Poemas Humanos, contudo, estas alusões à cidade servem como meio para situar ou explicar as atitudes emotivas do poeta. Como diz Reynolds (1970: 52): Em Poemas 
Humanos, a Vallejo não Ihe preocupam o relato do lugar, no sentido de história ou descrição: interessa-lhe o homem em si e seus semelhantes, sem tradição nem futuro. Somente ele, como é e com aquilo que existe na sua situação agônica e transitória pelo mundo".

\section{CONCLUSÃO}

Esse foi o caminho que percorreu a sua escrita e que lhe permitiu encarar a miséria da América, fazendo com que assumisse a convicção de que a escrita nunca pode ser neutra. Desse modo, ele se coloca cada vez mais a serviço da sociedade transmitindo uma visão crítica e vivendo também um espaço de solidariedade. Isso fará com que ele diga que:

A minha maior aspiração é a de eliminar toda palavra de existência acessória... uma vez que não se pode renunciar às palavras! Acredito sinceramente que a poesia possui um sentido histórico do idioma e que às apalpadelas procura, com justeza, a sua expressão (VALLEJO, 1992, p. 54) ${ }^{17}$.

Expressão que não ocorre sem ecos e leituras de leituras. E assim como as palavras falam de palavras, os gestos repetem os gestos, como "se honra el animal que me honra". E nesse jogo de duplicidades em que variados seres caminham um ao lado do outro, um disfarçado de outro, como nessa citação desse poema "España, aparta de mí este cáliz" (1937), em que a imagem da cidade do homem, "aposentos", e reflexos e falas e palavras percorrem esse túnel infinito e inusitado feito de vocábulos e cifras. O ser no tempo da vida é distinto do tempo no ser, mas ambos são, paradoxalmente, ao mesmo tempo, uma espécie de cainismo (de Caim, o ritualístico, fratricida, porém protegido de Deus) e abelismo (de Abel, o que apresentava a oferenda perfeita, vítima santa, o cordeiro a ser ele próprio oferecido em sacrifício). Assim, dever-se-ia propor, ao invés do ser no tempo, o tempo do ser. E o verbo então progrediria até realizar-se inteiramente em morrerei, morri, morro.

\section{REFERÊNCIAS}

BACHELARD, Gaston. A poética do espaço. Tradução Antônio Antonio de

\footnotetext{
17 Mi mayor aspiración es la eliminación de toda palabra de existencia accesoria....iya que no se puede renunciar a las palabras! Creo sinceramente que la poesía posuee un sentido histórico del idioma y que busca a tientas, con justicia, su expresión (VALLEJO, 1992, p. 54).
} 
Pádua Danes. 2. ed. São Paulo: Martins Fontes, 2008.

CANDELA, Germán Patrón. El Proceso Vallejo. Trujillo: Ed. Universidad Nacional de Trujillo, 1992.

FRANCO, Jean. La desautorización de la voz poética en dos poemas de Vallejo. Actas del coloquio internacional Freie Universität Berlin, 1981: 54-63. In: VALLEJO, Cesar. Obra poética. Ed. crítica, Américo Ferrari (Org.). Colección Archivos de la UNESCO, ALLCA XX/ São Paulo, EDUSP, 1996.

GIRARDOT, Gutierrez Rafael. La muerte de Dios en aproximaciones a César Vallejo, 1971:335-350. In: VALLEJO, Cesar. Obra poética. Ed. crítica, Américo Ferrari (Org.). Colección Archivos de la UNESCO, ALLCA XX/ São Paulo: EdUSP, 1996.

ORTEGA Y GASSET, José. A beleza foi feita para ser roubada. Tradução Ricardo Araújo. Brasília: Ed. UnB, 2013.

VALLEJO, César. Poesia completa. Tradução Thiago de Mello. Rio de Janeiro: Philobiblion/Rioarte, 1984.

VALLEJO, César. Antología Poética. Barcelona: Ediciones 29, 2000.

VALLEJO, César. El arte y la revolución: libro de pensamientos. Prólogo de Ricardo González VIGIL. Lima: Editora Perú, 2005. Disponível em: <http://www.scribd.com/doc/15789118/Cesar-Vallejo-El-Arte-y-LaRevolucion>. Acesso em: 26 nov. 2012.

VALLEJO, César. Escritos en prosa. Selección y estudio preliminar Claudia Caisso. Buenos Aires: Losada, 1994.

VALLEJO, César. Obra poética. Ed. crítica, Américo Ferrari (Org.). Colección Archivos de la UNESCO, ALLCA XX/ São Paulo: EDUSP, 1996.

\section{ANEXO}

LAS VENTANAS SE HAN ESTREMECIDO

Las ventanas se han estremecido, elaborando una metafísica del universo. Vidrios han caído. Un enfermo lanza su queja: la mitad por su boca lenguada y sobrante, y toda entera, por el ano de su espalda.

Es el huracán. Un castaño del jardín de las Tullerías habrase abatido, al soplo del viento, que mide ochenta metros por segundo. Capiteles de los barrios antiguos, habrán caído, hendiendo, matando. 
¿De qué punto interrogo, oyendo a ambas riberas de los océanos, de qué punto viene este huracán, tan digno de crédito, tan honrado de deuda, derecho a las ventanas del hospital?iAy las direcciones inmutables, que oscilan entre el huracán y esta pena directa de toser o defecar!iAy! Las direcciones inmutables, que así prenden muerte en las entrañas del hospital y despiertan células clandestinas, a deshora, en los cadáveres.

¿Qué pensaría de sí el enfermo de enfrente, ése que está durmiendo, si hubiera percibido el huracán? El pobre duerme, boca arriba, a la cabeza de su morfina, a los pies de toda su cordura. Un adarme más o menos en la dosis y le llevarán a enterrar, el vientre roto, la boca arriba, sordo al huracán, sordo a su vientre roto, ante el cual suelen los médicos dialogar y cavilar largamente, para, al fin, pronunciar sus llanas palabras de hombres.

La familia rodea al enfermo agrupándose ante sus sienes regresivas, indefensas, sudorosas. Ya no existe hogar sino entorno al velador del pariente enfermo, donde montan guardia impaciente, sus zapatos vacantes, sus cruces de repuesto, sus píldoras de opio. La familia rodea la mesita por espacio de un alto diviDendo. Una mujer acomoda en el borde de la mesa, la Taza, que casi se ha caído.

Ignoro lo que será del enfermo esta mujer, que le besa y no puede sanarle con el beso, le mira y no puede sanarle con los ojos, le habla y no puede sanarle con el verbo. ¿Es su madre?¿YY cómo, pues, no puede sanarle? Porque esta mujer le ha besado, le ha mirado, le ha hablado y hasta le ha cubierto mejor el cuello al enfermo y icosa verdaderamente asombrosa! no le ha sanado.

El paciente contempla su calzado vacante. Traen queso. Llevan tierra. La muerte se acuesta al pie del lecho, a dormir en sus tranquilas aguas y se duerme. entonces, los libres pies del hombre enfermo, sin menudencias ni pormenores innecesarios, se estiran en acento circunflejo, y se alejan, en una extensión de dos cuerpos de novios, del corazón.

El cirujano ausculta a los enfermos horas enteras. Hasta donde sus manos cesan de trabajar y empiezan a jugar, 
las lleva a tientas, rozando la piel de los pacientes, en tanto sus párpados científicos vibran, tocados por la indocta, por la humana flaqueza del amor. $Y$ he visto a esos enfermos morir precisamente del amor desdoblado del cirujano, de los largos diagnósticos, de las dosis exactas, del riguroso análisis de orinas y excrementos. Se rodeaba de improviso un lecho con un biombo. Médicos y enfermeros cruzaban delante del ausente, pizarra triste y próxima, que un niño llenara de números, en un gran monismo de pálidos miles. Cruzaban así, mirando a los otros, como si más irreparable fuese morir de apendicitis o neumonía, y no morir al sesgo del paso de los hombres.

Sirviendo a la causa de la religión, vuela con éxito esta mosca, a lo largo de la sala. A la hora de la visita de los cirujanos, sus zumbidos nos perdonan el pecho, ciertamente, pero desarrollándose luego, se adueñan del aire, para saludar con genio de mudanza, a los que van a morir. Unos enfermos oyen a esa mosca hasta durante el dolor y de ellos depende, por eso, el linaje del disparo, en las noches tremebundas.

¿Cuánto tiempo ha durado la anestesia, que llaman los hombres?iCiencia de Dios, Teodicea! isi se me echa a vivir en tales condiciones, anestesiado totalmente, volteada mi sensibilidad para adentro! iAh doctores de las sales, hombres de las esencias, prójimos de las bases!iPido se me deje con mi tumor de conciencia, con mi irritada lepra sensitiva, ocurra, lo que ocurra, aunque me muera! Dejadme dolerme, si lo queréis, mas dejadme despierto de sueño, con todo el universo metido, aunque fuese a las malas, en mi temperatura polvorosa.

En el mundo de la salud perfecta, se reirá por esta perspectiva en que padezco; pero, en el mismo plano y cortando la baraja del juego, percute aquí otra risa de contrapunto.

En la casa del dolor, la queja arranca frontera excesiva. no se reconoce en esta queja de dolor, a la propia queja de la dicha en éxtasis, cuando el amor y la carne se eximen de azor y cuando, al regresar, hay discordia bastante para el diálogo.

¿Dónde está, pues, el otro flanco de esta queja de dolor, si, a estimarla en conjunto, parte ahora del lecho de un 


\section{hombre?}

De la casa del dolor parten quejas tan sordas e inefables y tan colmadas de tanta plenitud que llorar por ellas sería poco, y sería ya mucho sonreír.

Se atumulta la sangre en el termómetro.

iNo es grato morir, señor, si en la vida nada se deja y si en la muerte nada es posible, sino sobre lo que se deja en la vida!

iNo es grato morir, señor, si en la vida nada se deja y si en la muerte nada es posible, sino sobre lo que se deja en la vida!

iNo es grato morir, señor, si en la vida nada se deja y si en la muerte nada es posible, sino sobre lo que pudo dejarse en la vida!

\section{AS JANELAS ESTREMECERAM - Tradução de Thiago de Mello}

As janelas estremeceram, elaborando uma

metafísica do universo. Vidros caíram. Um enfermo

solta a sua queixa: a metade pela boca transbordante de língua, e inteira pelo ânus de suas costas.

É o furacão. Uma castanheira dos jardins das Tulherias é derrubada pelo sopro do vento, que sopra a oitenta metros por segundo. Caíram capitéis do bairro antigo, fendendo, matando.

De que ponto, me pergunto ouvindo as duas margens dos oceanos, de que lugar vem este furacão tão digno de crédito, tão honrado de dívida, certeiro contra as janelas do hospital? Ai, as direções imutáveis que oscilam entre o furacão e essa dor de tossir ou defecar! Ai, as direções imutáveis, que semeiam a morte nas entranhas de um hospital e despertam a qualquer momento células clandestinas nos cadáveres.

O que pensaria de si o enfermo aí em frente, este que está dormindo, se houvesse percebido o furacão. O pobre dorme, de boca para cima, à cabeça de sua morfina, aos pés de toda a sua prudência. Um nadinha a mais ou a menos na sua dose e lá vai ser enterrado, o ventre roto, a boca para cima, surdo ao furacão, surdo a seu ventre roto, diante do qual os médicos costumam dialogar e cavilar demoradamente, para, finalmente, pronunciar suas triviais palavras de homens.

A família rodeia o doente, agrupando-se diante de suas têmporas regressivas, indefesas, suarentas. Já não existe lar, a não ser ali, em torno da mesa de cabeceira do parente enfermo, onde montam guarda impacientes seus sapatos vazios, suas cruzes de reserva, suas pílulas de ópio. A família rodeia a mesinha pelo espaço de um alto dividendo. Uma mulher acomoda bem, na beira da mesa, uma xícara que estava para cair. 
Quanto tempo durou a anestesia, como dizem os homens? Ciência de Deus, Teodicéia!, se me levam a viver em tais condições, totalmente anestesiado, minha sensibilidade voltada para dentro! Ah doutores dos sais, homens das essências, próximos das bases! Peço que me deixem com o meu tumor de consciência, com a minha irritada lepra sensitiva, aconteça o que acontecer, não faz mal que eu morra. Deixai que eu sofra, se quiserdes, mas me deixai desperto de sono, com o universo inteiro metido, mesmo que de má vontade, na minha temperatura polvorosa. (...)

Não é grato morrer, meu senhor, se na vida nada se deixa e se na morte nada é possível, a não ser sobre o que se deixa na vida!

Não é grato morrer, meu senhor, se na vida nada se deixa e se na morte nada é possível, a não ser sobre o que se deixa na vida!

Recebido em: 26/11/2021

Aceite em: 08/12/2021 